\title{
Attitudes towards organ donation in Syria: a cross-sectional study
}

\author{
Mario Tarzi, Malke Asaad, Joudi Tarabishi, Obada Zayegh* (10, Rama Hamza, Ahmad Alhamid, Aya Zazo \\ and Mohamad Morjan
}

\begin{abstract}
Background: The perception of organ donation and brain death among Syrian population has not been previously explored. The goal of this study is to evaluate the attitude and knowledge of organ donation among Syrians and the willingness of this population to donate their organs.
\end{abstract}

Methods: We conducted a survey-based cross-sectional study in four hospitals in Aleppo, Syria in November 2019. Patient demographic, awareness of brain death; and attitude toward organ donation were collected and analyzed.

Results: A total of 350 individuals were invited to participate in the survey among whom 303 (197 females, 106 males) agreed to participate in the study ( $87 \%$ response rate). The majority of our participants $(n=249,82 \%)$ heard about organ donation with television $(n=166,55 \%)$, social media $(n=77,25 \%)$, and the internet $(n=77,25 \%)$ being the most common sources of information. When assessing knowledge about brain death, only $40 \%(n=116)$ answered 3 or more questions (out of 5) correctly. Fifty-eight percent $(n=176)$ of respondents agreed with the idea of organ donation and 183 (62\%) would like to donate their organs one day. The leading motivation to organ donation was the desire to help $(n=234,77 \%)$, while the most common reason to refuse donation was the refusal to disfigure a dead body by removing an organ $(n=125,41 \%)$. Religious reasons were cited as motivation for organ donation by $43 \%$ of participants $(n=130)$, and a reason for refusing to donate organs by $24 \%(n=71)$. Most respondents $(n=261$, $88 \%$ ) were unaware of the laws and legislations related to organ donation in Syria. When asked if religion and law were encouraging organ donation, $76 \%$ of respondents $(n=226)$ would donate their organs. Although more positive attitude was found in those with better brain death knowledge (score $\geq 3$ ), this did not translate into more willingness to donate organs in this group of participants.

Conclusions: The promotion of organ donations from deceased donors is a necessity given the rising shortage of organs. The information provided by this study could help policy makers build future strategies to promote deceased organ donation programs and overcome current obstacles preventing such initiatives from achieving their goals.

Keywords: Organ, Donation, Transplant, Deceased, Brain death, Syria

\section{Background}

Our organs are subject to diverse types of changes, some of which could be reversed by the organs' regulatory systems, while others are irreversible and can lead to organ failure. Prior to the era of organ transplantation, management of several end-stage diseases was conservative

*Correspondence: obadazayegh@gmail.com

Faculty of Medicine, Aleppo University, Al-Mouhafaza, Aleppo, Syria without a viable alternative to the failed organ. However, remarkable progress in the fields of immunology and surgery has allowed medicine to triumph over many end-stage diseases, such as liver and kidney failure [1]. Not surprisingly, the great success of organ transplantation has yielded a significant increase of $70 \%$ in demand during the past decade [2-4]. Worldwide, the current imbalance between supply and demand in various organs (mainly liver and heart) results in over $20 \%$ of people on 
waiting lists dying every year before receiving the needed organ [5].

The history of organ transplantation in Syria is traced back to 1979, when the first kidney transplant was performed [6]. Later on, three cases of heart transplants were performed at Tishreen Military Hospital in the early 1990s. Two liver transplants were performed in 2017 and 2019 et al.-Assad University Hospital in Damascus. At the present time, kidney, cornea and bone marrow are the only organs being transplanted in Syria [7].

Organ transplantation in Syria mainly relied on living donors in 1980s. Since the enactment of Law number 30 in November 2003, a proper definition of "brain death" was made, and the permission of using organs from deceased donors in addition to living donors "both related and unrelated" was granted [7]. A recent update on the Law was made in 2009 which delineated the establishment of Syrian National Center for Organ transplantation [8]. However, this center has remained inactive and so has the national deceased organ donation program $[6$, 8].

The number of transplant surgeries performed in Syria has been significantly impacted by the ongoing war and such surgeries are currently performed in the capital, Damascus only. The number of total of kidney transplants went down from 385 (17 per million people, PMP) in 2010 to 154 in 2013 (6 PMP) [8]. There has been an increase in the rates of kidney transplants since then to reach 251 cases in 2018 (14 PMP), but it still lower than the numbers before the war (in 2010) [6]. The majority of these organs have been donated from living donors, mostly relatives, while deceased organ donation is still an unmet need. The promotion of organ donations from deceased donors is a necessity given the rising shortage of organs, but is still hinders by several obstacles. To the best of our knowledge, no study has evaluated the perception of organ donation and brain death among Syrian population. In this study, we aimed is to evaluate the attitude and knowledge of organ donation and brain death among Syrians and the willingness of this population to donate their organs. A secondary objective would be to assess the factors both precipitating and limiting organ donation. The information provided by this study could help policy makers build future strategies to promote deceased organ donation programs and overcome current obstacles preventing such initiatives from achieving their goals.

\section{Methods}

We conducted a survey-based cross-sectional study to assess attitudes towards organ donation among Syrian population. The questionnaire was designed based on literature review and experts' feedback [9-14]. The study was piloted on 13 individuals with no subsequent changes to the survey deemed necessary. We collected data on the following information: (1) demographic and socioeconomic characteristics of the participants; (2) knowledge and awareness of organ donation and brain death; and (3) attitude toward organ donation.

The questionnaire was delivered by trained medical students and conducted in-person with each participant. The survey was administered in November 2019, in Aleppo city, Syria. Four data collection centers were included: Aleppo University Hospital, Al-Shahba Private Hospital, Al-kalema Private Hospital, and Saint-Louis Private Hospital. We targeted all patients and visitors (inpatient and outpatient) of the study centers who were 18 years or older. We chose a combination of public and private hospitals to cover different socioeconomic classes of the Syrian society. The survey distributors explained the study to all participants. We obtained an informed verbal consent from all participants prior to participation in the study and an ethical approval from the research committee of the University of Aleppo prior to the conduction of the study. We administered the survey in Arabic which is the native language in Syria. An English and Arabic versions of the survey are presented in Additional files $1,2$.

\section{Statistical analysis}

Categorical variables were presented as frequencies and percentages, whereas numerical variables were presented as mean $\mp$ standard deviation (SD). We used Chi-square test and Fisher's exact test (when approporiate) to examine the relationship between categorical variables, and independent sample t-test to investigate the difference in mean age between groups. Five questions were asked to evaluate the knowledge of brain death. Participants were divided into two groups: brain death score $\geq 3$ if they answered 3 or more questions correctly; and brain death knowledge score $\leq 2$ if they answered 2 or less correct questions. A $p$ value $<0.05$ was considered statistically significant. Statistical analysis was performed using JMP Pro 14 software (JMP, Pro 14, SAS Institute Inc, Cary, NC, 1989-2019).

\section{Results \\ Participants demographics}

A total of 350 individuals were invited to participate in the survey among whom 303 agreed to participate in the study ( $87 \%$ response rate). Sixty-five percent of respondents were females $(n=197)$ and thirty-five percent were males $(n=106)$, with a mean age of $42 \mp 15$ years. The majority of the study participants were married $(n=217$, $72 \%$ ), without work (including retired and unemployed) $(\mathrm{n}=160,59 \%)$, and lived in urban $(\mathrm{n}=229,76 \%)$ as 
opposed to rural settings $(n=72,24 \%)$. Details on the demographic and socioeconomic characteristics of the participants are shown in Table 1.

\section{Knowledge of organ donation and brain death}

The majority of our participants $(n=249,82 \%)$ heard about organ donation with television $(\mathrm{n}=166,55 \%)$, social media $(n=77,25 \%)$, and the internet $(n=77$, $25 \%$ ) being the most common sources of information. Health-care workers as a source of information for organ donation was reported by only $11 \%$ of respondents. When assessing knowledge about brain death, only $40 \%$ $(n=116)$ answered 3 or more questions (out of 5) correctly. Table 2 summarizes participants' response to the questions related to the knowledge of organ donation and brain death.

\section{Attitude toward organ donation}

When assessing participants' attitude towards organ donation, $176(58 \%)$ of respondents agreed with the idea of organ donation, $183(62 \%)$ would like to donate

Table 1 Respondents demographic characteristics

\begin{tabular}{ll}
\hline & N (\%) \\
\hline Number of respondents & 303 \\
Age, years (mean ₹SD) & $42 \mp 15$ \\
Gender & \\
Male & $106(35)$ \\
Female & $197(65)$ \\
Residency & \\
Urban & $229(76)$ \\
Rural & $72(24)$ \\
Marital status & \\
Single & $59(20)$ \\
Married & $217(72)$ \\
Divorced & $7(2)$ \\
Widow & $18(6)$ \\
Level of education & \\
Illiterate & $32(11)$ \\
Less than high school & $144(48)$ \\
High school & $45(15)$ \\
College & $23(8)$ \\
University & $54(18)$ \\
Current job & \\
Private work & $34(12)$ \\
Employed & $79(29)$ \\
Does not work & $160(59)$ \\
Yes (treated) & \\
Yes (not treated) & $81(28)$ \\
No & $6(2)$ \\
\hline & $202(70)$ \\
\hline
\end{tabular}

Table 2 Awareness and knowledge of organ donation and brain death

N (\%)

Have you ever heard of organ donation?

Yes

$249(82)$

No

Where did you hear about organ donation? ${ }^{a}$

Television

$166(55)$

Newspapers and magazines $\quad 26$ (9)

Internet 77(25)

Educational center 17 (6)

Friends $\quad 57$ (19)

Family $\quad 40$ (13)

Health-care workers 34 (11)

As far as you are concerned, what do you relate organ donation to ? $^{a}$

Donation after death 187 (62)

Donation during life $\quad 160$ (53)

Brain death 51 (19)

Organ trafficking 52 (17)

Have you ever heard of brain death?

Yes $188(63)$

No 111 (37)

Do brain-dead patients respond if someone touched their eyes (by frowning, eye blinking, limb movement, etc.)?

Yes 24 (8)

No $89(30)$

Do not know $186(62)$

How do brain-dead patients keep their respiratory function?

$\begin{array}{ll}\text { By ventilator } & 137 \text { (46) }\end{array}$

Without the aid of any equipment 28 (9)

Do not know 134 (45)

Do brain-dead patients feel pain?

$\begin{array}{ll}\text { Yes } & 30(10)\end{array}$

No $117(39)$

Do not know 152 (51)

Is the recovery of brain-dead patients possible?

Yes 63 (21)

No 87 (29)

Do not know 149 (50)

As far as you are concerned, what is brain death related to? ${ }^{a}$

Coma 147 (49)

Vegetative state 24 (8)

Clinical death 157 (52)

Organ donation 45 (15)

${ }^{a}$ More than one answer was possible

their organs one day, and $200(67 \%)$ would encourage organ donation. However, when asked if they would agree to donate organs of a family member after death, 
the percentage of those who agreed went down to $50 \%$ $(n=149)$, which further went down when asked whether they would donate family members organs after brain death $(n=102,35 \%)$. Almost half of the respondents would donate organs only after death $(\mathrm{n}=121,51 \%)$, while $28 \%(n=68)$ would donate anytime and $21 \%$ $(\mathrm{n}=50)$ would donate only during life.

The leading motivation to organ donation was the desire to help $(n=234,77 \%)$, while the most common reason to refuse donation was the refusal to act with corpses $(n=125,41 \%)$. Religious reasons were cited as motivation for organ donation by $43 \%$ of participants $(\mathrm{n}=130)$, and a reason for refusing to donate organs by $24 \%(n=71)$. Most respondents $(n=261,88 \%)$ were unaware of the laws and legislations related to organ donation in Syria. If religion and law were encouraging organ donation, $76 \%$ of respondents $(n=226)$ would donate their organs. Respondents' attitudes toward organ donation are summarized in Table 3.

\section{Relationship between brain death knowledge and organ donation}

Participants demographics were similar between those who scored brain death score $\geq 3$ and brain death knowledge score $\leq 2$ except higher education level in those who scored $\geq 3$. Although more positive attitude was found in those with better brain death knowledge (score $\geq 3$ ), this did not translate into more willingness to donate organs in this group of participants. Demographics and attitude toward organ donation by brain death knowledge are summarized in Table 4.

\section{Relationship between desire to donate and participants' demographics}

Markedly, neither socioeconomic and demographic factors nor knowledge of brain death were significantly associated with willingness to donate. However, donation patterns differed between those who are willing to donate and those not. Table 5 represents the factors related to willingness to donate organs.

\section{Discussion}

Exploring the attitude of people towards organ donation is of vital importance in developing strategies to increase social awareness of organ donation and eliminate any fears associated with this process. In our study, we found that the majority of our participants are willing to donate their organs, driven by the pure desire to help others, both relatives and non-relatives. We did not identify a significant association between brain death's knowledge and the willingness to donate organs. Most respondents were unaware of the laws and legislations related to organ donation in Syria and if the latter two were encouraging organ donation, more respondents are likely to donate their organs. Addressing misconceptions through awareness programs could potentially close the current gap between donors and recipients.

The results of our survey reveal that the majority of the participants $(82 \%)$ heard about organ donation. This corresponds with the results of prior studies [9, 12, 15]. A study from Egypt found that $89 \%$ of the participants have heard of organ donation, while $53 \%$ of them could recognize the organs that could be transplanted [9]. Our findings reflect that the majority $(62 \%)$ of the study group was willing to donate their organs. This percentage is higher than that in Qatar (35.7\%), Egypt (44\%), and Nigeria $(29.7 \%)[2,9,12]$, similar to that of Jordan $(67 \%)$ and Pakistan (62\%) $[16,17]$ and lower than its counterpart in the US (98\%) [18]. Although the majority tends to donate their organs to anyone in need on altruistic motive, almost $35 \%$ would donate only to their relatives. "Relatives are priority when doing favor" is what many of the participants have referred to when explaining their point. Preference to donate organs to relatives has also been reported in other countries like Egypt [9], Brazil [19] and Saudi Arabia [10]. Relatives' impact would exceed the former point to a new one, which is the tendency to donate the organs of their beloved ones after death but not after being diagnosed with brain death. It can be explained with the misunderstanding of the concept of brain death, as $21 \%$ of the study group believe that recovery could happen for a brain-dead patient [20-22]. The previous result highlights the role of health facilities in explaining the correct definition of brain death and how donated organs can be the glimpse of hope for other people in need.

Several sources can serve to educate individuals about organ donation. In our study, television seems to be the main method of knowledge about organ donation. The television, social media, and the internet have permitted sharing of medical information and provided many platforms for the purpose of promoting the general public health. This could be interpreted by the relatively low cost, ease of usage and reach for many people compared to other sources of information. This seems to be the case in other countries as well $[9,10]$. However, the credibility of the information provided on these platforms are questionable and need further validation. On the other hand, Health Care Workers (HCWs) were the source of information in only $11 \%$ of the respondents despite being a more accurate source of information [9], and their interactions could influence the final decision of the family $[23,24]$. HCW should be targeted by government policies to be the major source of information when it relates to organ donation. This can be applied by engaging the HCWs' system in specific workshops on various topics 


\section{Table 3 Attitude towards organ donation}

\begin{tabular}{|c|c|}
\hline & $\mathrm{N}(\%)$ \\
\hline \multicolumn{2}{|l|}{ What is your attitude toward organ donation? } \\
\hline Agree & $176(58)$ \\
\hline Disagree & $76(25)$ \\
\hline Do not know & $50(17)$ \\
\hline \multicolumn{2}{|l|}{ Would you like to donate an organ or more one day? } \\
\hline Yes & $183(62)$ \\
\hline No & $112(38)$ \\
\hline \multicolumn{2}{|l|}{ When would you prefer to donate your organs? } \\
\hline Only during life & $50(21)$ \\
\hline Only after death & $121(51)$ \\
\hline Any time & $68(28)$ \\
\hline \multicolumn{2}{|c|}{ Would you agree to donate organs of a family member after their death? } \\
\hline Yes & $149(50)$ \\
\hline No & $148(50)$ \\
\hline \multicolumn{2}{|c|}{ Would you agree to donate organs of a family member in cases of brain death? } \\
\hline Yes & $102(35)$ \\
\hline No & $191(65)$ \\
\hline \multicolumn{2}{|l|}{ Would you encourage organ donation? } \\
\hline Yes & $200(67)$ \\
\hline No & $99(33)$ \\
\hline \multicolumn{2}{|l|}{ Who would you want to donate your organs to? } \\
\hline Only for relatives & $94(35)$ \\
\hline Only for non-relatives & $1(0.3)$ \\
\hline Relatives and non-relatives & $174(65)$ \\
\hline \multicolumn{2}{|c|}{ In case you agreed to donate your organs, what would your motivations be? } \\
\hline Financial & $5(2)$ \\
\hline Religious & $130(43)$ \\
\hline It does not harm, so why not? & $125(41)$ \\
\hline The desire to help & $234(77)$ \\
\hline \multicolumn{2}{|c|}{ In case you disagreed to donate your organs, what would the reasons be? } \\
\hline Absence of financial benefit & $5(2)$ \\
\hline Religious beliefs & $71(24)$ \\
\hline Social and familial barriers & $88(29)$ \\
\hline Refusing to act with corpses & $125(41)$ \\
\hline Fear of being murdered in order to obtain organs & $117(39)$ \\
\hline Fear of not receiving a good medical care & $104(34)$ \\
\hline Fear of talking about death & $29(10)$ \\
\hline Lack of knowledge about organ donation & $75(25)$ \\
\hline Organs recipients are not chosen fairly & $121(40)$ \\
\hline \multicolumn{2}{|c|}{ Are you aware of the laws and legislations related to organ donation, brain death and organ transplantation in Syria? } \\
\hline Yes & $37(12)$ \\
\hline No & $261(88)$ \\
\hline \multicolumn{2}{|c|}{ If religion and law were encouraging organ donation, would you do it? } \\
\hline Yes & $226(76)$ \\
\hline No & $70(24)$ \\
\hline \multicolumn{2}{|l|}{ Do you have an experience with organ donation? } \\
\hline Yes & $2(1)$ \\
\hline No & $297(99)$ \\
\hline \multicolumn{2}{|c|}{ If we conducted a lecture about organ donation, would you attend it? } \\
\hline Yes & $87(29)$ \\
\hline No & $215(71)$ \\
\hline
\end{tabular}


Table 4 Attitude towards organ donation by brain death knowledge

\begin{tabular}{|c|c|c|c|c|}
\hline & $\begin{array}{l}\text { Brain death } \\
\text { knowledge } \\
\text { score } \leq 2 \mathrm{~N}(\%)\end{array}$ & $\begin{array}{l}\text { Brain death } \\
\text { knowledge } \\
\text { score } 3 \geq N(\%)\end{array}$ & $\begin{array}{l}\text { Total } \\
\text { N (\%) }\end{array}$ & $p$ value \\
\hline No. (\%) & $176(60)$ & $116(40)$ & 292 & \\
\hline Age, years (mean $\mp S D$ ) & $42 \mp 15$ & $41 \mp 15$ & & 0.55 \\
\hline \multicolumn{5}{|l|}{ Gender } \\
\hline Male & $58(33)$ & $44(38)$ & $102(35)$ & \multirow[t]{2}{*}{0.38} \\
\hline Female & $118(67)$ & $72(62)$ & $190(65)$ & \\
\hline \multicolumn{5}{|l|}{ Residency } \\
\hline Urban & $130(74)$ & $90(78)$ & $220(76)$ & \multirow[t]{2}{*}{0.44} \\
\hline Rural & $45(26)$ & $25(22)$ & $70(24)$ & \\
\hline \multicolumn{5}{|l|}{ Education } \\
\hline Illiterate/less than high school & $119(69)$ & $51(44)$ & $70(59)$ & \multirow[t]{2}{*}{$<.0001$} \\
\hline High school or higher & $53(31)$ & $64(66)$ & $117(41)$ & \\
\hline \multicolumn{5}{|l|}{ Current job } \\
\hline Does not work & $99(62)$ & $55(53)$ & $154(59)$ & \multirow[t]{2}{*}{0.13} \\
\hline Works & $60(83)$ & $49(47)$ & $109(41)$ & \\
\hline \multicolumn{5}{|l|}{ Marital status } \\
\hline Not married & $44(25)$ & $37(32)$ & $81(28)$ & \multirow[t]{2}{*}{0.18} \\
\hline Married & $132(75)$ & $78(68)$ & $210(72)$ & \\
\hline \multicolumn{5}{|l|}{ Chronic diseases } \\
\hline Not treated & $113(69)$ & $81(70)$ & $194(70)$ & \multirow[t]{2}{*}{0.84} \\
\hline Absent or treated & $50(31)$ & $34(30)$ & $84(30)$ & \\
\hline \multicolumn{5}{|c|}{ What is your attitude toward organ donation? } \\
\hline Agree & $96(55)$ & $74(64)$ & $170(58)$ & \multirow[t]{3}{*}{$0.02^{*}$} \\
\hline Disagree & $43(24)$ & $32(28)$ & $75(26)$ & \\
\hline Do not know & $37(21)$ & $10(9)$ & $47(16)$ & \\
\hline \multicolumn{5}{|c|}{ Would you like to donate an organ or more one day? } \\
\hline Yes & $113(65)$ & $66(57)$ & $179(62)$ & \multirow[t]{2}{*}{0.17} \\
\hline No & $60(35)$ & $49(43)$ & $109(38)$ & \\
\hline \multicolumn{5}{|c|}{ When would you prefer to donate your organs? } \\
\hline Only during life & $31(22)$ & $18(21)$ & $49(21)$ & \multirow[t]{3}{*}{0.78} \\
\hline Only after death & $70(49)$ & $46(53)$ & $116(51)$ & \\
\hline Any time & $42(29)$ & $22(26)$ & $64(28)$ & \\
\hline \multicolumn{5}{|c|}{ Would you agree to donate organs of a family member after their death? } \\
\hline Yes & $86(50)$ & $59(51)$ & $145(50)$ & \multirow[t]{2}{*}{0.89} \\
\hline No & $86(50)$ & $57(49)$ & $143(50)$ & \\
\hline \multicolumn{5}{|c|}{ Would you agree to donate organs of a family member in cases of brain death? } \\
\hline Yes & $55(32)$ & $42(37)$ & $97(34)$ & \multirow[t]{2}{*}{0.43} \\
\hline No & $115(68)$ & $72(63)$ & $187(66)$ & \\
\hline \multicolumn{5}{|c|}{ Would you encourage organ donation? } \\
\hline Yes & $111(64)$ & $81(70)$ & $192(66)$ & 0.32 \\
\hline No & $62(36)$ & $35(30)$ & $97(34)$ & \\
\hline $\begin{array}{l}\text { Are you aware of the laws and le } \\
\text { and organ transplantation in S }\end{array}$ & & & & \\
\hline Yes & $18(10)$ & $17(15)$ & $35(12)$ & 0.25 \\
\hline No & $156(90)$ & $97(85)$ & $253(88)$ & \\
\hline If religion and law were encoura & & & & \\
\hline Yes & $127(73)$ & $91(80)$ & $218(76)$ & 0.21 \\
\hline No & $46(27)$ & $23(20)$ & $69(24)$ & \\
\hline
\end{tabular}

\footnotetext{
* Statistically significant
} 
of interest and emphasizing the value of providing them with up-to-date information. Setting websites managed by HCWs for the public to refer to whenever they have questions could be a useful step as well.

We evaluated various factors affecting the willingness of organ donation. The pure desire to help followed by religious reasons were the two most frequent reasons for donating organs while financial reasons were only motivating for $2 \%$ of respondents. This could be explained by the belief that getting paid for good actions curtail the good deed and that profiting from organ donation is another form of organ trafficking.

A study from Jordan has found that religious (36\%) and lack of financial incentive (44\%) constitute important reasons to refuse organ donation [13]. Another study from Saudi Arabia reflected that humanity (68\%) and religious (62\%) reasons are the most important to accept organ donation, while money has only accounted for $0.6 \%$ [10]. In the same study, religion was a reason for refusing to donate organs in $27.5 \%$ of respondents.

Maintenance of body's integrity is one of the main concerns of our study group, reflected by "Refusing to act with corpses" (disfiguring the body of the donor following death in order to obtain organs) being chosen as the most common cause for refusal to donate organs. This idea goes in line with what Sanner et al. has stated, "those who are in favor of cremation and those who are not concerned about the disfiguration of the body tend to have a favorable attitude toward organ donation" [25]. People should be informed that the process of organ donation is handled in an operative setting by professional doctors who take the best care of the deceased patient and following which the body is returned to the family for a possible Open Casket funeral. Mistrust in medical staff, represented by fear of being murdered to obtain organs and bias in choosing recipients, constituted other major reasons for the disapproval of organ donation. Some also has the misconception that removing an organ might result in the donor's death. The psychologic effects presented by fear and insecurity, that prevail at times of war could potentially exacerbate patients' mistrust in the medical system. Governmental interventions should focus on addressing patient mistrust and misinformation about organ donation in the hope of increasing the number of those willing to donate. Clarity and transparency in organ distribution among all citizens of different financial and social status are needed to ensure equal opportunities in receiving organ transplantations. Seventeen percent of the respondents related organ donation to organ trafficking. This fear could have been fueled by several reports of organ traffickers preying on Syrian refugees [26, 27]. However, no studies or official numbers exist in that regard.
Understanding factors related to organ donation is key in any policy intervention trying to address this issue. Brain death knowledge is a fundamental factor that is correlated deeply with organ donation, as the majority of organs donated are those of brain-dead patients [28]. Our study depicts that $40 \%$ of our participants had good knowledge of brain death, yet almost half of the participants relate brain death to coma, which illustrates a profound misunderstanding of the pathophysiology of brain death. Participants with better brain death knowledge demonstrated a favorable attitude towards organ donation, but they were not more likely to donate their organs. This is in contrast to many studies that showed correspondence between the two entities [29, 30]. Mistrust in the practical application of organ donation could potentially explain the lack of association in our study.

Future projects aiming to increase the rates of organ donation in Syria should take into consideration the importance of "family pattern" when it comes to sign the final decision of organ donation, the necessity of scientific sessions about drain death and organ donation to dispel community myths and encourage people to donate. The role of transparency in choosing recipients is vital in ways of increasing the trust in the noble role of the medical team. Individuals could be asked routinely about their willingness to donate during application to official documents from the government (e.g. driver license) with available educational resources for those who need more information prior to making a decision [9]. Religious and legal factors play a critical role in the decision for organ donation as more people might be willing to donate if religion and law were encouraging organ donation. Interestingly, both law and religion in Syria allow for organ donation. The enactment of law number "30" defines an important landmark in the progress of organ donation legalization process in Syria. It characterized the concept of brain death, allowed the donation of deceased organs and expanded living organ donation to both related and unrelated recipients [7]. Moreover, Islam and Christianity, the two main religions in Syria, stand for organ donation and permit it for the benefit of people in need. Therefore, churches and mosques could play an important role in informing people about the position of both Islam and Christianity from organ donation. In addition, awareness programs are crucial to educate people since only $12 \%$ are aware of laws related to organ donation in Syria. Distinguishing organ donation during from that after life and addressing the misconceptions associated with deceased organ donation could help improve the rates of those willing to donate after life. The current lack of a national organ donation registry limits the ability to match donors with those in need 
Table 5 Attitude towards organ donation by desire to donate organs

\begin{tabular}{|c|c|c|c|c|}
\hline & $\begin{array}{l}\text { Desire } \\
\mathrm{N}(\%)\end{array}$ & $\begin{array}{l}\text { No desire } \\
\mathrm{N}(\%)\end{array}$ & $\begin{array}{l}\text { Total } \\
\mathrm{N}(\%)\end{array}$ & $p$ value \\
\hline No. (\%) & $183(62)$ & $112(38)$ & 295 & \\
\hline Age, years (mean $\mp$ ) & $43 \pm 15$ & $40 \pm 14$ & & 0.13 \\
\hline \multicolumn{5}{|l|}{ Gender } \\
\hline Male & $63(34)$ & $39(35)$ & $102(35)$ & \multirow[t]{2}{*}{0.94} \\
\hline Female & $120(66)$ & $73(65)$ & $193(65)$ & \\
\hline \multicolumn{5}{|l|}{ Residency } \\
\hline Urban & $143(78)$ & $81(74)$ & $224(76)$ & \multirow[t]{2}{*}{0.38} \\
\hline Rural & $40(22)$ & $29(26)$ & $69(24)$ & \\
\hline \multicolumn{5}{|l|}{ Education } \\
\hline Illiterate or less than high school & $112(62)$ & $61(55)$ & $173(59)$ & \multirow[t]{2}{*}{0.24} \\
\hline High school or higher & $69(38)$ & $50(45)$ & $119(41)$ & \\
\hline \multicolumn{5}{|l|}{ Current job } \\
\hline Does not work & $99(61)$ & $57(55)$ & $156(59)$ & \multirow[t]{2}{*}{0.35} \\
\hline Works & $63(39)$ & $46(45)$ & $109(41)$ & \\
\hline \multicolumn{5}{|l|}{ Marital status } \\
\hline Not married & $53(29)$ & $30(27)$ & $83(28)$ & \multirow[t]{2}{*}{0.72} \\
\hline Married & $130(71)$ & $81(73)$ & $211(72)$ & \\
\hline \multicolumn{5}{|l|}{ Chronic diseases } \\
\hline Not treated & $114(66)$ & $83(75)$ & $197(70)$ & \multirow[t]{2}{*}{0.10} \\
\hline Absent or treated & $58(34)$ & $27(25)$ & $85(30)$ & \\
\hline \multicolumn{5}{|c|}{ Have you ever heard of organ donation? } \\
\hline Yes & $152(83)$ & $90(80)$ & $242(82)$ & \multirow[t]{2}{*}{0.56} \\
\hline No & $31(17)$ & $22(20)$ & $53(18)$ & \\
\hline \multicolumn{5}{|l|}{ Brain death knowledge score } \\
\hline Brain death knowledge score $\leq 2$ & $113(63)$ & $60(55)$ & $173(60)$ & \multirow[t]{2}{*}{0.17} \\
\hline Brain death knowledge score $\geq 3$ & $66(37)$ & $49(45)$ & $115(40)$ & \\
\hline \multicolumn{5}{|c|}{ When would you prefer to donate your organs? } \\
\hline Only during life & $41(23)$ & $8(15)$ & $49(21)$ & \multirow[t]{3}{*}{$<.0001^{*}$} \\
\hline Only after death & $76(42)$ & $39(75)$ & $115(50)$ & \\
\hline Any time & $63(35)$ & $5(10)$ & $68(29)$ & \\
\hline \multicolumn{5}{|c|}{ Would you agree to donate organs of a family member after their death? } \\
\hline Yes & $120(66)$ & $28(25)$ & $148(51)$ & \multirow[t]{2}{*}{$<.0001^{*}$} \\
\hline No & $61(34)$ & $83(75)$ & $144(49)$ & \\
\hline \multicolumn{5}{|c|}{ Would you agree to donate organs of a family member in cases of brain death? } \\
\hline Yes & $87(48)$ & $14(13)$ & $101(35)$ & \multirow[t]{2}{*}{$<.0001^{*}$} \\
\hline No & $94(52)$ & $93(87)$ & $187(65)$ & \\
\hline Would you encourage organ donati & & & & \\
\hline Yes & $157(86)$ & $38(35)$ & $195(67)$ & $<.0001^{*}$ \\
\hline No & $26(14)$ & $71(65)$ & $97(33)$ & \\
\hline Who would you want to donate you & & & & \\
\hline Only for relatives & $48(26)$ & $46(56)$ & $94(36)$ & $<.0001^{*}$ \\
\hline Only for strangers & $1(1)$ & $0(0)$ & $1(0)$ & \\
\hline To anyone & $132(73)$ & $36(44)$ & $168(64)$ & \\
\hline $\begin{array}{l}\text { Are you aware of the laws and legisl } \\
\text { transplantation in Syria? }\end{array}$ & & & & \\
\hline Yes & $23(13)$ & $14(13)$ & $37(13)$ & 1.00 \\
\hline No & $158(87)$ & $96(87)$ & $254(87)$ & \\
\hline If religion and law were encouragin & & & & \\
\hline Yes & $167(91)$ & $54(50)$ & $221(76)$ & $<.0001^{*}$ \\
\hline No & $16(9)$ & $53(50)$ & $69(24)$ & \\
\hline
\end{tabular}

* Statistically significant 
[6]. Providing donors with a donor card or having an app that match donors with recipients would streamline the process of organ donation and improve access for patients in need.

There are several limitations in our study that worth highlighting. The survey we used was not validated given the lack of validated survey for assessment of organ donation. This may have introduced bias in our study. Our study assessed 4 hospitals in one Syrian city, and the results might not be generalizable to other settings. However, we included hospitals from various areas of the city belonging to both the private and public sectors to ensure the diversity and representability of our sample. Finally, patients and their companions could be more likely to favor organ donation compared to the general population, given their health or their relatives health status. Future studies should assess the efficacy of various interventions to improve awareness of organ donations and willingness to donate organs, during and after life.

\section{Conclusions}

The promotion of organ donations from deceased donors is a necessity given the rising shortage of organs. We found that the majority of our participants are willing to donate their organs, driven by the pure desire to help others. Fear of disfiguring a dead body by removing an organ and mistrust in the recipients' selection process were the main deterrents of organ donation. We did not find significant association between brain death's knowledge and the willingness to donate organs. The information provided by this study could help policy makers build future strategies to promote deceased organ donation programs and overcome current obstacles preventing such initiatives from achieving their goals.

\section{Supplementary Information}

The online version contains supplementary material available at https://doi. org/10.1186/s12910-020-00565-4.

Additional file 1. English version of the survey.

Additional file 2 . Arabic version of the survey.

\section{Abbreviations}

PMP: Per million people; HCWs: Health care workers.

\section{Acknowledgements}

The authors wish to thank and acknowledge the assistance provided by Kenda Kanjo and Nour Chehneh during the survey distribution.

\section{Authors' contributions}

MT conducted the literature review, prepared the questionnaire, participated in distributing the questionnaire, performing group interviews, collecting and entering data and writing the manuscript. MA conceived of the idea of the research, edited the questionnaire, analyzed data, and reviewed the manuscript. JT participated in distributing the questionnaire, performing group interviews, and entering the data. OZ entered data and reviewed the manuscript. $\mathrm{RH}$ participated in distributing the questionnaire, performing group interviews, and entering the data. AA contributed to and reviewed the manuscript. AZ participated in distributing the questionnaire and contributed to and reviewed the manuscript. MM approved, reviewed, and edited both the survey and the manuscript. All authors read and approved the final manuscript

\section{Funding}

None.

\section{Availability of data and materials}

The data that support the findings of this study are available on request by the journal. The data are not publicly available due to institution research privacy policy.

\section{Ethics approval and consent to participate}

Ethical approval was obtained by the board of Faculty of Medicine at Aleppo University. Verbal consent was approved for this study.

\section{Consent for publication}

Verbal consent was obtained for all participants. The institution does not require written consent form for researches that do not include confidential information, personal information, or interventions on patient.

\section{Competing interests}

No competing interests to be declared.

Received: 16 June 2020 Accepted: 30 November 2020

Published online: 09 December 2020

\section{References}

1. Human Organ Transplantation. https://www.who.int/transplantation/ organ/en/.

2. Odusanya OO, Ladipo CO. Organ donation: knowledge, attitudes, and practice in Lagos, Nigeria. Artif Organs. 2006;30(8):626-9.

3. Potts JT Jr, Herdman R. Non-heart-beating organ transplantation: medical and ethical issues in procurement. Washington: National Academies Press; 1997

4. Ehrle RN, Shafer TJ, Nelson KR. Referral, request, and consent for organ donation: best practice-a blueprint for success. Crit Care Nurse. 1999;19(2):21-30, 32-23 (quiz 35-26).

5. Cantarovich F. Improvement in organ shortage through education. Transplantation. 2002;73(11):1844-6.

6. Saeed B. How did the war affect organ transplantation in Syria? Exp Clin Transplant. 2020a;18(Suppl 1):19-21.

7. Saeed B, Derani R, Hajibrahim M, et al. Organ failure in Syria: initiating a national deceased donation program. Saudi J Kidney Dis Transplant. 2007;18(2):270-6

8. Saeed B. Organ transplantation in Syria. Transplantation. 2020b;104(5):889-92.

9. Afifi RM, Zaytoun SS, Khan EA, Afifi Y. Public's attitude toward organ donation in Egypt: a social and conceptual approach. J Adv Med Med Res. 2016;18(7):1-15. https://doi.org/10.9734/BJMMR/2016/29797.

10. Alam AA. Public opinion on organ donation in Saudi Arabia. Saudi J Kidney Dis Transplant. 2007;18(1):54-9.

11. Barcellos FC, Araujo CL, da Costa JD. Organ donation: a population-based study. Clin Transplant. 2005;19(1):33-7.

12. El-Shoubaki H, Bener A. Public knowledge and attitudes toward organ donation and transplantation: a cross-cultural study. Transpl Proc. 2005;37(5):1993-7.

13. Hammad S, Alnammourah M, Almahmoud F, Fawzi M, Breizat AH. Questionnaire on brain death and organ procurement. Exp Clin Transplantation. 2017:15(Suppl 1):121-3.

14. Ralph AF, Alyami A, Allen RD, et al. Attitudes and beliefs about deceased organ donation in the Arabic-speaking community in Australia: a focus group study. BMJ Open. 2016;6(1):e010138. 
15. Hajjar WM, Bin Abdulqader SA, Aldayel SS, Alfardan AW, Alzaidy NI. Knowledge, attitudes, and beliefs toward organ donation among social media users. Transpl Proc. 2016;48(7):2418-22.

16. Haddad MF, Khabour OF, Alzoubi KH, Bakkar MM. Public attitudes toward corneal donation in northern Jordan. Clin Ophthalmol (Auckland, NZ). 2018;12:1973-80.

17. Saleem $T$, Ishaque $S$, Habib $N$, et al. Knowledge, attitudes and practices survey on organ donation among a selected adult population of Pakistan. BMC Med Ethics. 2009:10:5.

18. Sander SL, Miller BK. Public knowledge and attitudes regarding organ and tissue donation: an analysis of the northwest Ohio community. Patient Educ Couns. 2005;58(2):154-63.

19. Coelho JC, Ciliao C, Parolin MB, et al. Opinion and knowledge of the population of a Brazilian city about organ donation and transplantation. Rev Assoc Med Bras (1992). 2007;53(5):421-5.

20. Conesa C, Rios A, Ramirez P, Canteras M, Rodriguez MM, Parrilla P. Multivariate study of the psychosocial factors affecting public attitude towards organ donation. Nefrologia. 2005;25(6):684-97.

21. Conesa C, Rios A, Ramirez P, et al. Psychosocial profile in favor of organ donation. Transpl Proc. 2003;35(4):1276-81.

22. Conesa C, Rios Zambudio A, Ramirez P, Canteras M, del Mar RM, Parrilla P. Socio-personal profile of teenagers opposed to organ donation. Nephrol Dial Transplant. 2004;19(5):1269-75.

23. Feeley TH, Tamburlin J, Vincent DE. An educational intervention on organ and tissue donation for first-year medical students. Progress Transplant (Aliso Viejo, Calif). 2008;18(2):103-8.
24. Rykhoff ME, Coupland C, Dionne J, et al. A clinical group's attempt to raise awareness of organ and tissue donation. Progress Transplant (Aliso Viejo, Calif). 2010;20(1):33-9.

25. Sanner M. A comparison of public attitudes toward autopsy, organ donation, and anatomic dissection. A Swedish survey. JAMA. 1994;271(4):284-8.

26. Forsyth A. Meeting an organ trafficker who preys on Syrian refugees. BBC. 25 Apr 2017. https://www.bbc.com/news/magazine-39272511. Accessed 30 Sep 2020.

27. Capatides C, Williams H. Desperate Syrian refugees are resorting to selling their organs on the black market just to pay rent. CBS News. 19 May 2020. https://www.cbsnews.com/news/desperate-syrian-refugees-selli ng-organs-to-survive/. Accessed 30 Sep 2020.

28. Council of Europe. International figures on donation and transplantation 2015. Newsletter Transplant 2016:16.

29. Rios A, Cascales P, Martinez L, et al. Emigration from the British Isles to southeastern Spain: a study of attitudes toward organ donation. Am J Transplant. 2007;7(8):2020-30.

30. Rodrigue JR, Fleishman A, Fitzpatrick S, Boger M. Organ donation knowledge, willingness, and beliefs of motor vehicle clerks. Transplantation. 2014;98(10):1025-8.

\section{Publisher's Note}

Springer Nature remains neutral with regard to jurisdictional claims in published maps and institutional affiliations.
Ready to submit your research? Choose BMC and benefit from:

- fast, convenient online submission

- thorough peer review by experienced researchers in your field

- rapid publication on acceptance

- support for research data, including large and complex data types

- gold Open Access which fosters wider collaboration and increased citations

- maximum visibility for your research: over $100 \mathrm{M}$ website views per year

At BMC, research is always in progress.

Learn more biomedcentral.com/submissions 